\title{
Integrative and Instrumental Motivations for Learning English as a University Requirement among Undergraduate Students at Al-Jazeera University/Dubai
}

Dr. Mohammed Hamid Al-Ta'ani (corresponding author)

\author{
Assistant professor \\ Department of English Language \& Translation \\ Emirates Canadian University College \\ Umm-Al-Quwain, United Arab Emirates
}

Tel: 971-557-483-918Ｅ-mail: dr.mattar1989@hotmail.com

Received: October 8, 2018 Accepted: November 7, 2018 Published: November 20, 2018

doi:10.5296/ijld.v8i4.13940 URL: https://doi.org/10.5296/ijld.v8i4.13940

\begin{abstract}
This paper attempted to investigate the Emirati EFL (English as a Foreign Language) learners' integrative and instrumental learning motivation at Al-Jazeera University, Dubai, UAE. The data were collected through a modified (20-item) motivational questionnaire adapted from Gardner's (1985). (50) students; from which (36) students were males (72\%) and the remaining (14) ones were females (28\%) participated in answering a questionnaire which reflected their motivation towards learning English as a mandatory university requirement. The findings revealed that the students had high level of motivation-both integrative and instrumental for learning English, but their instrumental motivation was slightly surpassed their integrative one in this study. The data analysis concerning the open-ended question showed that writing skill was the most problematic area for the students. Based on the findings, some suggestions, guidelines and recommendations for future research, English teachers, teaching process and policy makers were highlighted.
\end{abstract}

Keywords: Motivation, instrumental motivation, integrative motivation, EFL learners 


\section{Introduction}

From my experience in teaching English in various educational institutions in Jordan and the UAE for many years, I found most of my students were either motivated extrinsically or demotivated.

Motivating EFL [English as a Foreign Language] learners has witnessed much more attention during the past decades and the importance of motivation has been regarded by many educational psychologists as a crucial factor which affects learners' success or failure in any educational process especially in learning a foreign language. This has urged many teachers, educators and researchers to investigate the role of motivation in learning-teaching process. According to (Gardner \& Lambert, 1972; Gardner, 1985, 2010; Dornyei, 2005; Bernaus \& Gardner, 2008) motivation is a key predictor of success in learning a language. Learners' failure or success has been explained by the degree of their motivation (Chalak \& Kassaian, 2010)( as cited in Badeleh et al., 2017) which is considered as a key to learning in general, and language learning in particular.(Dornyei, 1998).(Winke,2013 and Ellis,1994) say that motivation has a substantial effect on foreign language acquisition. So, researching and examining the role of motivation in learning English as a foreign language has got considerable attention by linguists and educators.

As teachers and university professors, we often miss that all of our learning teaching activities are filtered through our students' motivation. Students control the flow of the classroom. Without students' motivation, the classroom atmosphere becomes boring and lifeless. Therefore, it is important to think about our students' motivation as the core of language teaching.

The research on motivation defines motivation as an orientation toward a goal. This orientation may be positive, negative or ambivalent. Motivation is considered as a source of energy that explains why learners decide to exert efforts and how long they are willing to help in an activity. Woolfolk (1995) defines "Motivation as an internal state that arouses, directs and maintains behavior." Salvin in Rehman (2014, 345) defines "Motivation as an internal process that activates, guides and maintains behavior over time.”

From these definitions motivation can be considered as a process that influences the success of the target language leaning. (Bligh, 1971; Sass, 1989) mention many factors that can affect our students' motivation toward learning English as a second language. The factors are: The learner's
a) interest in the subject matter.
b) perceptions of its usefulness.
c) self-confidence \& self-esteem.
d) general desire to achieve.
e) patience and persistence.

Brown (2000) classified studies of motivation of target or foreign language learners into two 
types:

a) Instrumental motivation.

b) Integrative motivation.

Gardner (1983) defines instrumental motivation as "Learning a language because of someone or less clearly perceived utility it might have for the learner.”(p. 2003). More specifically, a learner is instrumentally motivated when s/he has the desire to learn a language "to pass an exam, to use it when visiting a foreign country and to get a well-paid job." (Wilkins, 1972, p. 184).Gardner and Lambert (1992) considered instrumental motivation as a means to get social and economic rewards through second language learning.

On the other hand, Chalak and Kassaian (2010) state that integrative motivation is "The desire to learn second language/foreign language to communicate with the people of the second language society and mix up in their culture." Integrative motivation refers to "an openness to identify at least in part with another language community." (Gardner \& Masgoret, 2003, P. 126).

Ellis (1997) pointed that motivation varies from person to person depending on learning context and task. (p. 76).

So the purpose of this paper is to investigate the motivation type which is more common among Emirati University students learning English as a foreign language.

\subsection{Definition of Terms}

Motivation: is the internal drive that pushes and drives somebody to do and achieve something. While Punmanee (1991) views motivation as the process aroused by stimulus to achieve desired purposes, behaviors or conditions. Motivation is a continuous process which is based on a person's desire and interests.

Instrumental Motivation: is the learners' interest in learning a language for getting essential qualifications and improving career prospects.

Integrative Motivation: is the learners' desire to learn a language so that they can communicate with confidence with a speaking community.

\section{Literature Review}

A number of studies have been conducted on second language learners' motivation towards learning English as a foreign/second language in different areas of the world including the UAE. The students studying at undergraduate level in various colleges at Al-Jazeera University are to conduct their study in English, so English is the medium of instruction in most of the University colleges. Therefore, it is important to investigate their motivations towards learning English. In the following, the researcher will explore some studies done on the second language learners' motivation towards learning English.

Sohbani (1997) conducted a study on Yemeni secondary school students in three governorates. He attempted to examine the attitudes and motivation of those students toward English 
Language learning. He found that most of Yemeni students had favorable attitudes and considerable high motivation regarding English Language Learning. He also noticed that the more the learners positively evaluate their English teacher, the more motivated they become to learn English. He also found that the students tended to make inadequate efforts in studying and learning English.

Hedge (2000) explored the motivation of (30) Japanese students who were studying English. The study results showed that the most common reasons for studying English as a second language were for communication with people overseas, finding employment in a high profile career, possessing international information and understanding other cultures. This revealed that the subject were instrumentally and integratively motivated.

Al-Quyadi (2002) did a study on Yemeni Students .He intended to investigate the attitudes and motivation of Yemeni EFL learners at the Department of English. Faculties of Education at Sana'a University toward learning English. A questionnaire was distributed to 518 students representing seven faculties of Education. He found that the students were both instrumentally and integratively motivated. They also had positive attitude towards the English Language and the use of English in the Yemeni social and educational contexts.

Qashoa (2006) piloted a study on secondary students in Dubai. His purpose was to investigate the students' motivation for learning English and to identify the factors affecting learners' motivation. He found that the students' instrumental motivation was higher than integrative motivation. Further, difficulties related to English vocabulary, structures and spelling were reported to be the most demotivating factors for such learners.

Rahman (2007) carried out a study on Bangladeshi students. He found that they tended to learn English with instrumental motivation more than integrative one.

Gonzale (2010) conducted a study on Filipino foreign language learners. The results revealed that the learners were both extrinsically and intrinsically motivated.

Tsai and Chang (2010) made a study on [45] elderly EFL learners' integrative and instrumental learning motivation in Taiwan. He found that the learners were more instrumentally motivated.

Wimolmas (2012) examined (30) first year undergraduate students from Sirindhorn International Institute of Technology (SIIT), Thammasat University, who were studying in the second semester of the academic year 2012. The study attempted to examine the type and level of English Language learning motivation (instrumental or integrative). A modified motivational questionnaire of (20) items adapted from Gardner's Attitude/ Motivation Test Battery was administered. The results showed that the students were relatively "highly" motivated and found to be slightly more "instrumentally" motivated to learn English. This revealed that instrumental motivation was a significant factor among this group of students learning English. In the light of the study's findings, some useful and relevant implications were recommended for improvement of the students' motivation.

Kitjaroonchai (2013) conducted a study on (266) students from (10) different secondary and 
high schools in Education Service Area (4), Saraburi Province. This study aimed to investigate the English language learning motivation of students with high academic achievement and that of other learners. A modified motivational questionnaire of (20) items adapted from Gardner's Attitude/Motivation Test Battery was administered. The findings indicated that the students had high levels of motivation- both instrumental and integrative-to learn the English Language, although their instrumental motivation slightly outperformed their integrative motivation. The study also showed that there was a significant differences $(\mathrm{P}$-value $=0.007)$ at the level of0.01 between the learning motivation of students with high academic achievement $(\mathrm{GPA} \geq 3.20)$ and that of other peers $(\mathrm{GPA}=3.20)$.

Mohammed (2015) did a study which attempted to examine the anxiety level and the motivation patterns of Saudi College students of English and how motivational patterns and anxiety effect on language learning. The subjects (75) students who were randomly selected from Community College and faculty of Education at Sharqa University. The researcher used (SPSS) program to elicit the results. The results revealed that the students were very anxious towards learning EFL and motivated instrumentally more than integratively.

Ali (2017) carried out a study on (40) Sudanese English Foreign Language (EFL) learners (20) males and (20) females in Neelain University graduate students (fourth year). The study results showed that $(80 \%)$ of male EFL students studied English so that they can change their lives and immigrate to European countries, to be a part of these communities. So, they practiced integrative motivation. Also, it showed that (60\%) of female EFL students studied the English Language to be able to enroll in higher studies to get Master degree in the English Language and find opportunities in the Gulf Area. So they practiced instrumental motivation.

\section{Methodology}

\subsection{Participants}

The participants of this study were (50), (36) male and (14) female undergraduate students whose ages ranged between 20-38 years old at University of Al-Jazeera/Dubai. They were studying English Communication Skills as a university requirement in the second semester of the academic year 2015/2016.

Those participants require taking two English Language courses, English (1) and English (2) as obligatory courses for all university students regardless their major. The fact that all participants are joined from different majors at the University helps provide various views about their second language learning motivations.

These courses put emphasis on the four basic language skills: reading, writing, listening and speaking to help them develop basic communication skills in addition to comprehend and understand the culture of the native speakers.

\subsection{Data Collection Instrument}

The instrument used for collecting the data was a motivational questionnaire and an open-ended question. 


\section{Macrothink}

International Journal of Learning and Development

ISSN 2164-4063

2018, Vol. 8, No. 4

The motivational questionnaire was a five-point Likert Scale which was adopted from the original 7-Likert Scale format of Gardner's (1985) Attitude, Motivation Test Battery (AMTB) with the integrative and instrumental Scales.

The questionnaire consisted of (20) items and ranged from strongly agree (5) to strongly disagree (1). The questionnaire was designed with some modifications to suit the students. These items were taken from Gardner and Lambert Model (1972).

The questionnaire consisted of the following three sections:

Section (1) The Participants' Background Information.

This section was designed to elicit information on demographic and educational profile of the participants.

Section (2) Instrumental and integrative motives.

The questionnaire consisted of 20 items measuring the students' motivation towards learning English language. The first (10) items were designed to measure the participants' instrumental motivation. While the items (11-20) were used to measure the participants' integrative motivation towards English and the English Speaking Community.

Since the participants came from different academic backgrounds and different levels of proficiency in English, the questionnaire was translated orally into Arabic by the researcher, who taught those students, to ensure that the participants understand the items accurately and fully and to avoid any confusion.

Section (3) an open-ended question on students' major problems that affect their level of motivation while learning English.

\subsection{Reliability of the Instrument}

For content reliability, a pilot study was administered on (15) university students other than the participants of the study. The questionnaire reliability was computed using Cronbach Alpha Analysis. The overall reliability was (0.78) which is acceptable to administer the questionnaire.

\subsection{Validity of the Instrument}

To ensure that the content of the questionnaire was valid, it was given to (3) experts and language specialists from University of Al-Jazeera to comment on. Upon their comments some items were deleted and others were modified.

\subsection{Procedures and Data Collection}

Before carrying out the questionnaire, it was assured that the participants had no objection to participating in this study. The participants were assured that the information would be strictly confidential and used for research purposes and wouldn't impact on their grades.

The questionnaire was distributed to (50) students during their normal classes. A close supervision by the researcher was given during the administration. The questionnaire 


\section{Macrothink}

International Journal of Learning and Development

ISSN 2164-4063 2018, Vol. 8, No. 4

instructions were explained by the researcher himself. The participants were given half an hour to answer the questionnaire. The distributed questionnaires were collected directly after completing them.

\subsection{Objectives of the Study}

This study was conducted to:

a) determine the motivational level of the undergraduate students at University of Al-Jazeera.

b) detect if they were more integratively or instrumentally motivated towards learning English.

\subsection{Questions of the Study}

This study was conducted to find the answers to the following questions:

a) What is the level of motivation among the undergraduate students who are learning English as a university requirement at University of Al-Jazeera?

b) Are the participants mainly integratively or instrumentally motivated towards learning English as a university requirement?

c) Which language skill(s) seem(s) to be the most problematic skill for the participants?

\section{Data Analysis}

The data collected from the distributed questionnaires were computed and analyzed by using Statistical Package for the Social Sciences (SPSS) as follows:

a) The participants' data related to general background were computed and shown in percentages.

b) The researcher used a five-point Likert Scale to interpret the participants' level of motivation and type of learning motivation. The researcher adopted Best(1981) and Degang's (2010) scale to specify the level of agreement or disagreement as follows:

Table 1. Interpretation of mean score of motivation levels

\begin{tabular}{llll}
\hline Scale & Mean range & Motivational Level & Score range \\
\hline 5 & Strongly agree & Highest & $4.50-5.00$ \\
4 & Agree & High & $3.50-4.49$ \\
3 & Moderate & Moderate & $2.50-3.49$ \\
2 & Disagree & Low & $1.50-2.49$ \\
1 & Strongly disagree & Lowest & $1.00-1.49$ \\
\hline
\end{tabular}

The mean score for each item was used to indicate the participants' motivational level; the 


\section{Macrothink}

International Journal of Learning and Development

ISSN 2164-4063 2018, Vol. 8, No. 4

higher mean score means that the participants are highly motivated, while the lower mean score implies that they are low motivated.

\subsection{Findings \& Discussions}

The 50 participants were (36) male and (14) female students aged between 20-38 years old. They were in various years of study ranging from first to fourth year. Figure 1 shows the percentage of participants in each year of study.

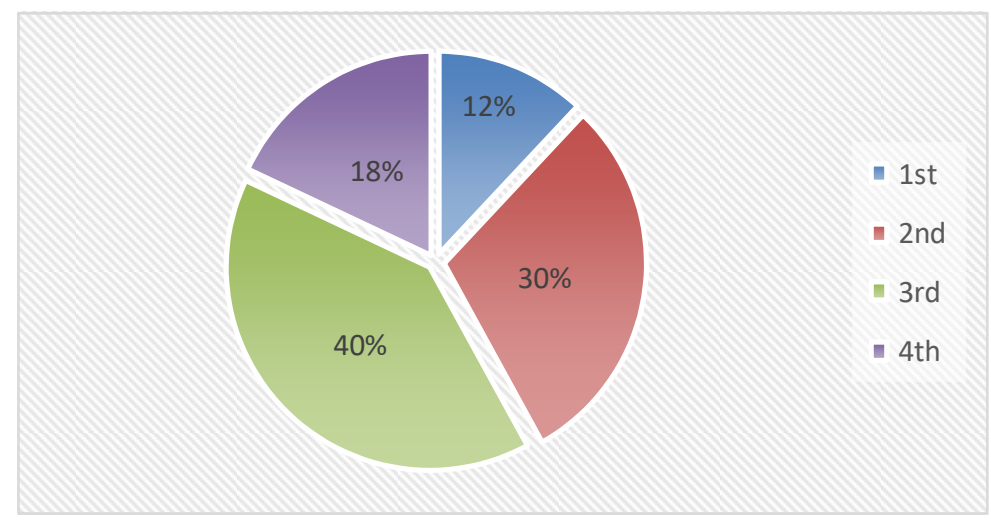

Chart 1 percentages of the participants in each year of study

The findings of this study were classified into three sections:

Section (1) General information.

This section shed light on the participants' general demographic data. The results were based on the distributed questionnaires as follows:

Table 2. Participants'sex

\begin{tabular}{ll}
\hline Sex & Percent \% \\
\hline Male & $72 \%$ \\
Female & $28 \%$ \\
Total & $100 \%$ \\
\hline
\end{tabular}

As shown in table 1 the predominant respondents were males (72\%), while the minor $(28 \%)$ were females. This could be because male respondents were seeking for getting a university degree especially those who are in militaries. Getting a university degree is the UAE Government basic requirement for promotion and getting a salary bonus. 


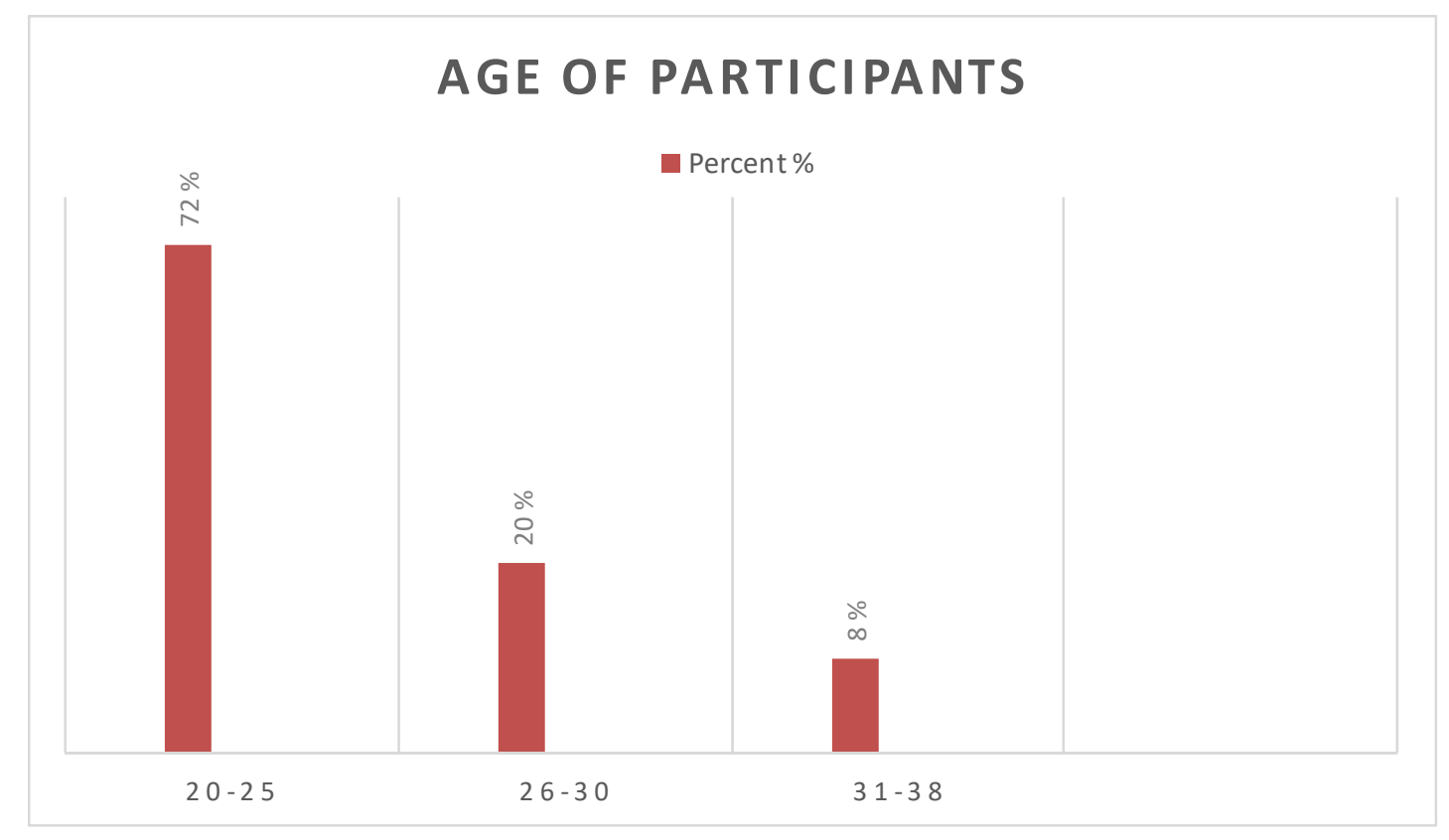

Chart 2. The relationship between the age and number of the respondents

Obviously, chart 2 shows the relationship between the age and the number of participants in this study. A number of (50) undergraduate students were chosen as the sample of this study. According to the chart, a considerable number of students (36) (or 72\%) were between 20-25 years old, whereas (10) of them or (20\%) were at the age of 26-30 and (4) were from 31 to 38 years old and accounting for $(8 \%)$ of the entire sample.

Table 3. Overall mean score and average mean scores for instrumental and integrative motivational types

\begin{tabular}{lccc}
\hline Type of mean scores & Mean & Motivational Level \\
\hline Average mean score for instrumental motivation & 4.24 & High \\
Average mean score for integrative motivation & 3.88 & High \\
Overall mean score & 4.06 & High \\
\hline
\end{tabular}

As illustrated in table 3, the overall mean score is (4.06) which means that the participants are highly motivated to learn the English Language. The average mean score of instrumental motivation was higher compared to the integrative average mean scores (4.24) and (3.88) to learn English as a university requirement respectively. It is also apparent that both fall in the high motivational level, and the participants' instrumental motivational level slightly 
surpassed their integrative one by (0.36).

The results of this study harmonize with Liu (2005); Quashoa (2006); Kuiper (2007); Kyriacou and Zhu (2008); (Moiinvaziri's, 2010); Al-Ahmadi (2011); Choonsri and Intharaksa (2011); MunRahman (2014); Mohammed (2015) and (Masum, 2016, 2011); Kitjaroochai (2012); Muneera and Shameem (2013) Abdur and Rehman (2014).

Table 4. Mean scores of instrumental motivation items and their motivational level

\begin{tabular}{|c|c|c|c|}
\hline NO & Instrumental Motivation & Mean & $\begin{array}{l}\text { Motivational } \\
\text { Level }\end{array}$ \\
\hline 1 & I mainly focus on using English for class assignments and exams. & 3.45 & Moderate \\
\hline 2 & $\begin{array}{l}\text { I simply quote the textbooks and do not really communicate myself when } \\
\text { speaking or writing in class. }\end{array}$ & 4.39 & High \\
\hline 3 & $\begin{array}{l}\text { I am interested in reading only English textbooks for my university study, but } \\
\text { not other English texts e.g. newspapers, magazines. }\end{array}$ & 4.43 & High \\
\hline 4 & Learning English is important because it will be useful in getting a good job. & 4.83 & Very high \\
\hline 5 & $\begin{array}{l}\text { I am more interested in furthering my higher education than learning English } \\
\text { Language itself. }\end{array}$ & 4.47 & High \\
\hline 6 & Learning English is very important for travelling abroad. & 4.65 & Very high \\
\hline 7 & Learning English is very important for making me a more educated person. & 3.41 & Moderate \\
\hline 8 & $\begin{array}{l}\text { Learning English is very important for making me a knowledgeable and } \\
\text { skillful person. }\end{array}$ & 4.83 & Very high \\
\hline 9 & $\begin{array}{l}\text { Being proficient in English can lead to more success and achievements in } \\
\text { life. }\end{array}$ & 4.50 & Very high \\
\hline 10 & Being proficient in English makes other people respect me. & $3 . .41$ & Moderate \\
\hline
\end{tabular}

Table 5. Mean scores of integrative motivation items and their motivational level

\begin{tabular}{llll}
\hline NO & Integrative Motivation & Mean & $\begin{array}{l}\text { Motivational } \\
\text { Level }\end{array}$ \\
\hline 11 & $\begin{array}{l}\text { Studying English enables me to understand English books, stories, } \\
\text { movies...etc. }\end{array}$ & High \\
12 & $\begin{array}{l}\text { Studying English enables me to better understand and appreciate the ways of } \\
\text { life of native speakers. }\end{array}$ & 4.35 & High \\
13 & $\begin{array}{l}\text { Studying English enables me to be able to keep in touch with foreign } \\
\text { acquaintances. }\end{array}$ & 4.15 & High \\
14 & $\begin{array}{l}\text { Studying English enables me to discuss interesting issues in English with the } \\
\text { people from other national backgrounds. }\end{array}$ & 4.32 & High \\
15 & $\begin{array}{l}\text { Studying English enables me to transfer my knowledge to other people, for } \\
\text { example, giving directions to a tourist. }\end{array}$ & 4.51 & Very high \\
\hline 16 & $\begin{array}{l}\text { Studying English enables me to participate freely in academic, social, and } \\
\text { professional activities among other cultural groups. }\end{array}$ & 4.08 & High
\end{tabular}


Studying English enables me to speak like native speakers: e.g. accent, tone and using English expressions.

3.56

High

18 Studying English enables me to appreciate English art and literature.

19 Studying English enables me to be an open-minded and sociable person.

20 Studying English enables me to achieve maximum proficiency.
2.56 Moderate

3.78 High

3.05 Moderate

Tables (4 and 5) shed light on the questionnaire items that scored the highest mean scores and the ones with the lowest mean scores. Two items under instrumental motivation category had similar mean scores of (4.83) which are the highest scores of the questionnaire results. Such mean scores are considered very high according to the rating motivational level (Table 1).

Table 4. clarifies that items (4 and 8) Learning English is important because it will be useful in getting a good job and learning English is very important for making me a knowledgeable and skillful person (mean $=4.83$ ) respectively. This implies that the participants are aware of the importance of learning English as a means of getting a good job and improving and developing their knowledge. Item (6) learning English is very important for travelling abroad (mean=4.65). This means that the participants are highly motivated to learn English and enthusiastic about travelling aboard due to their richness and the hot weather during summer vacations. They are also willing to learn English due the nature of their country which receives millions of tourists every year of different nationalities.

Items (1 and 10) relatively have low mean scores that show the participants' are moderately motivated for these statements as shown below:

Item (1) I mainly focus on using English for class assignments and exams with an average mean score $=3.45$. This item falls under the category of "moderate" which implies that the participants are less interested in learning English for doing class assignments and preparing for exams.

Item number (10) Being proficient in English makes other people respect me with a moderate average mean score $=3.41$. This shows that the participants are unsatisfied with this statement. This agrees with Moiinvaziri (2010) who found that Iranian students don't necessarily need other people's respect concerning English proficiency. So, people's respect does not have a strong influence on their English learning motivation.

As revealed in table 3, the participants had a high level of integrative motivation with a high average mean score (3.88). As illustrated in table (5), Items (15,11,12, and 14) (i.e Studying English enables me to transfer my knowledge to other people, for example, giving directions to a tourist, Studying English enables me to understand English books, stories, movies...etc., Studying English enables me to better understand and appreciate the ways of life of native speakers, and Studying English enables me to discuss interesting issues in English with the people from other national backgrounds.) indicate the highest level of integrative motivation with the mean scores $(4.51,4.43,4.35$ and 4.32) respectively. This implies that the respondents may become aware of the importance and value of being in contact with 


\section{Macrothink}

foreigners. While items (18 and 20) (Studying English enables me to appreciate English art and literature.) and Studying English enables me to achieve maximum proficiency.) achieve the lowest average mean score $=(2.56)$ and (3.05) respectively and they fall under the category of "moderate" motivational level. This indicates that English Art and Literature are still something far above their comprehension and appreciation (Degang, 2010).

\subsection{Findings of the Open-ended Question}

This section outlined the main English Language difficulties faced by the participants when they responded to the open-ended question.

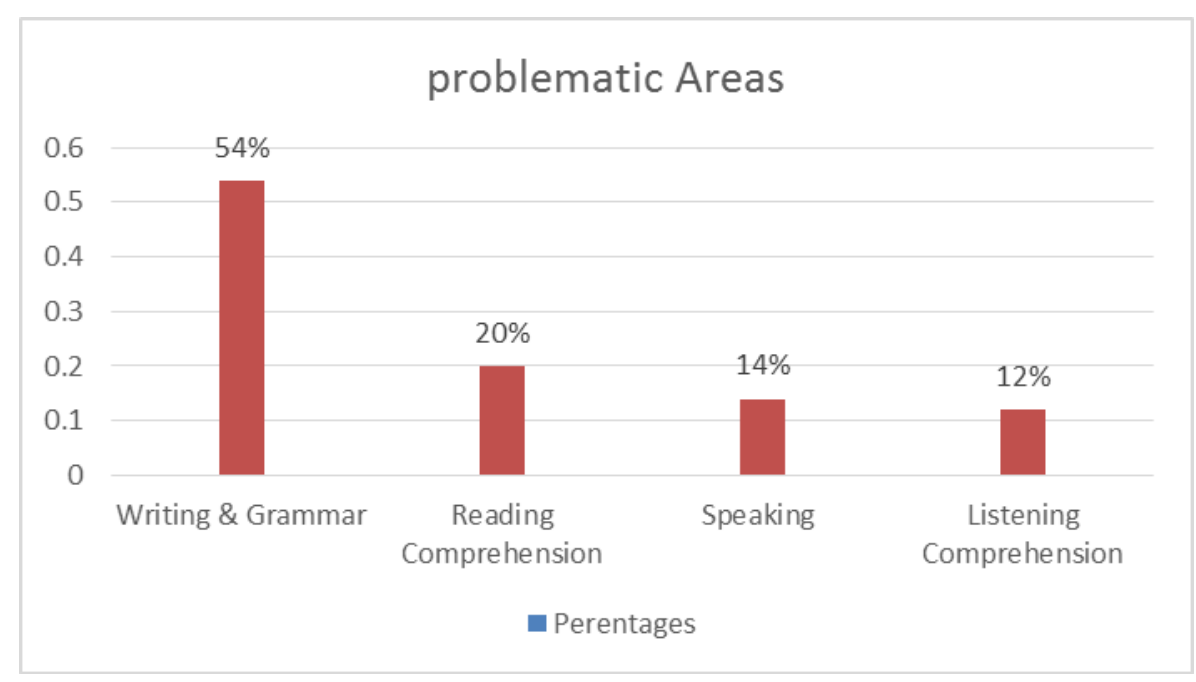

Chart 3. English language difficulties facing the participants when studying English

Clearly, the results of the open-ended question revealed that writing skill had the highest percentage of 54\%. The respondents reported that writing skill was the most problematic area, this idea was confirmed by Watcharapunyawong and Usaha (2012) who found that writing was the most difficult for EFL learners to master, because they had major problems with grammar, vocabulary and meaning, which were classified first; they were followed by writing mechanics (i.e., spelling, punctuation and capitalization). Also, they explained that their problems were due to the fact that they did not think in English; they said that they thought in Arabic, and then they translated their thoughts into English. They agreed that writing was a strenuous task not only because of interference of Arabic, but also because of their lack of grammatical rules.

Reading skill scored as the second most problematic skill to the respondents $(20 \%)$ due to the misunderstanding of the reading process, insufficient linguistic competence in general, and practice of reading in particular, differences between English and Arabic and the English spelling/sound system.

Speaking skill (14\%) was rated the third most difficult skill to be mastered. This may be because of the respondents' low self-confidence in their ability to communicate in English, the absence of English speaking in classes, the allocated time for teaching the speaking skill in classes is insufficient to accomplish many communicative activities provided to the 
students, the little opportunity to communicate in English in real life situations, since the participants live in an Arab speaking country and most of their teaching staff members are non-native speakers, the lack of exposure to English inside and outside classes, being criticized by their instructors or colleagues when they commit speaking mistakes and the inappropriateness of the content textbook to students' daily speaking needs which results in difficulty in understanding the content of the syllabus.

Listening comprehension (12\%) is regarded as the least problematic skill. The respondents stated that it is a problem for them because of lack of control over the speakers' speed; inability to concentrate; their unfamiliar and limited vocabulary and accents and the long listening texts. In addition, the school environment is not always conducive to teaching listening skills, i.e. noise factor, room set up etc. This indicates that the respondents seem to be familiar with listening since they practice more listening and speaking in their daily lives and because of the multilingual nature of the residents.

\section{Conclusion and Pedagogical Implications}

It was noticed that the level of instrumental motivation was higher than the level of integrative motivation among the participants, but, however, their integrative motivation was also high. This is consistent with motivational studies done by (Liu et al., 2011), Muftah and Galea (2013) and Masum (2016). This emphasizes that in most of the countries where English is taught as a second language, learners are more instrumentally motivated rather than integratively.

Instrumentally motivated students want to learn English language for a practical reason such as getting a salary bonus or joining a university. Many university non-English majors have a clear instrumental motivation for learning English language: They want to fulfill a university language requirement. While students with an Integrative motivation want to learn English to understand and know the people who speak it well.

Although the respondents were highly motivated to learn English, they showed that there were some difficulties and problems in the English Language process. They rated writing and grammar as the most problematic to be mastered, followed by reading, speaking and listening. The difficulties related to writing skill could be overcame by following various strategies such as providing students with the sources of writing materials so that students can study better, providing topics of interest and related to the school curriculum. (Smadi, 1985; p.35) said "The topics that are brought live to students will always give results that have never been expected.", encouraging students to use different activities to improve writing skill, such as keep a journal, poster presentation and editing processes, raising students' confidence because this helps them to monitor and self-correct own errors to improve their overall accuracy, brainstorming, making checklists for students to do the peer-review or self-evaluation, teaching the basics and strategies of writing in general will help students to write and produce a well coherent piece of writing and organizing writing competitions among faculties in universities or schools. As for reading skill problems, the researchers suggest some remedies: 1) Students should be patient with unfamiliar words. 2) Students can play enjoyable free internet games that review basic phonics. 3) Students can play search games with words and 
letters which are confusing. For example, if they face difficulty in mixing up the letters $\underline{b}$ and $\underline{\mathrm{d}}$, give them a newspaper or any other print out and ask them to underline each b's. They are encouraged to use scanning strategy. 4) Students can use reference tools such as a dictionary. 5) Instructors and students can schedule a regular time for practicing extensive reading. 6) Instructors can encourage class journals in which students summarize, react to, and express their feeling towards the readings. While other skills, i.e. speaking and listening should not be ignored since all the four language skills are to be practiced in each English class to increase the students' actual production.

\section{Recommendations \& Future Studies}

Based on the results of the study and their discussion, the researcher presents some recommendations for future researches, professors, teachers and syllabus designers. It is recommended to: 1) examine motivation in English Language learning of the students of speaking majors. 2) conduct a more detailed study about the difficulties related to the four skills as the results of the open-ended question indicated. 3) design a classroom environment that promotes the students' motivation towards learning English and student center.4) increase language courses for non-English departments to strengthen all the language skills. 5) conduct a further study including a larger sample which would make the study more valid and reliable. 6) use other methods and techniques for collecting data other than questionnaires such as observation, interviews ---etc. that would be more valid and reliable. 7) conduct a study on the integration of technology in classroom and the level of motivation.8) conduct a study on the relationship between the students' profile (i.e. parents' jobs, educational background and language used at home) and the level and type of motivation towards learning English as a second language.

\section{References}

Al-Ahmadi, M. R. (2011). The Effect of Integrative and Instrumental Motivation on Iranian EFL Learners' Language Learning. ELT Voices- India, 97-104.

Abdur- Rehman, A., Bilal, H., Sheikh, A., Bibi, N., \& Nawaz, A. (2014). The role of motivation in learning English language for Pakistani learners. International Journal of Humanities and Social Science, 4(1), 254-258.

Ali, M.E. (2017). Types of Motivation among Sudanese Learners. International Journal of Education and Social Science. 4 (2), 33-36.

Al-Quyadi, A. (2002). Psycho-sociological Variables in the Learning of English in Yemen. Ph.D. Thesis. Bhagalpur University.

Al-Sobbani, Y. A. (1997). Attitudes and Motivation of Yemeni Secondary School Students and English Language Learning. Unpublished Ph.D. Thesis, Department of English, University of Pune, India.

Badeleh, M. T., and et, al. (2017). The Type and Reliable Predictors of Motivation: A Case of 


\section{Macrothink}

International Journal of Learning and Development

ISSN 2164-4063 2018, Vol. 8, No. 4

Iranian EAP Learners. International Journal of English Language \&translation Studies. 5(01), 101-110.

Bernaus, M., \& Gardner, R. C. (2008). Teacher Motivation Strategies, Student Perceptions, Student Motivation and English Achievement. The Modern Language Journal, 92, 387-401. https://doi.org/10.1111/j.1540-4781.2008.00753.x

Best, J. W. (1981). Research in Education. $5^{\text {th }}$ edition. Englewood Cliffs. New Jersey: Prentice Hall.

Bligh, D. A. (1971). What's the Use of Lecturing? Devon, England: Teaching Services Center, University of Exeter.

Brown, H. D. (2000). Principles of Language Learning and Teaching. New Jersey: Prentice Hall.

Chalak, A., \& Kassaian. (2010). Motivation and Attitudes of Iranian Undergraduate EFL Students toward Learning English. GEMA online journal of language studies. 10 (2).

Choosri, C., \& Intharaksa, U. (2011). Relationship between Motivation and Students' English Learning Achievement: A study of the second Year Vocational Certificate Level Hatyai Technical College Students. Retrieved February 10, 2013 from http:// sv.libart.psu.ac. th/ conference 5/ proceedings/ Proceedings 3 / article/ 006.pdf

Csize'r, K., \& Dornyei, Z. (2005).The Internal Structure of Language "Learning Motivation and its Relationship with Language Choice and Learning Effort." Modern Language Journal, 89(1), 19-36. https://doi.org/10.1111/j.0026-7902.2005.00263.x

Degang, M. (2010). Motivation toward English Language Learning of the Second Year Undergraduate Thai Students Majoring in Business English at English-Medium University. Srinakharinwirot University

Ellis, R. (1994a). The Study of Second Language Acquisition. London: Oxford University Press.

Ellis, R. (1997 b). Second Language Acquisition. Oxford University Press.

Gardner, A., \& Masgoret, A. M. (2003). Attitudes, Motivation and Second Language Learning: A Meta-Analysis of Studies conducted by Gardner and Associates. Language Learning, 53, 123-163. https://doi.org/10.1111/1467-9922.00212

Gardner, R. C., and et al. (1983). The socio-educational model of second language acquisition: An investigation using LISREL causal modeling. Journal of language and social psychology, 2(1), 1-15., 51-65. https://doi.org/10.1177/0261927X8300200101

Gardner, R. C. (1985). Social Psychology and Second Language Learning: The Role of Attitudes and Motivation. London: Edward Arnold

Gardner, R. C., \& Lambert, W. E. (1972). Attitudes and Motivation in Second Language Learning. Rowley, MA: Newbury House Publishers 
Gonzales, R. D. (2010). Motivational Orientation in Foreign Language Learning: The case of Filipino Foreign Language Learners. TESOL Journal, 3, 3-28.

Hedge, T. (2000). Teaching and Learning in the Language Classroom. Oxford: Oxford University Press.

Kitjaroonchai, N., \& Kitjaroonchai, T. ((2012). Motivation toward English Language Learning of Thai Students Majoring in English at Asia- Pacific International University. Catalyst, 7(1), 21-40.

Kitjaroonchai, N. (2012). Motivation toward English Language Learning of Students in Secondary and High Schools in Education Service Area Office 4, Saraburi Province, Thailand. International Journal of Language and Linguistics. 1(2), 22-33.

Kuiper, A. (2007). Communication in a foreign Environment. Proceedings of the Association for Business Communication $7^{\text {th }}$ Asia-Pacific Conference. Copyright 2007, Association for Business Communication

Kyriacou, C., \& Zhu, D. (2008). Shanghai Pupil's Motivation towards Learning English and the Perceived Influence of the Important Others. Educational Studies, 34(2). https://doi.org/10.1080/03055690701811099

Liu, M. (2007). Chinese Students' Motivation to Learn English at the Tertiary Level. Retrieved from http:// www.asian-efl-journal. Com/ March_07_ml.php

Masum, Z. H. M. J. (2016). Motivation of Bangladeshi Higher Secondary Students in Learning English Language. Language in India, 16(2), February, 2016. WWW.languageinindia.com

Mohammed, A. (2015). EFL Effective Factors: Anxiety and Motivation and their Effect on Saudi College Student's Achievement. Arab World English Journal (AWEJ), 6(2), 201-218. https://doi.org/10.24093/awej/vol6no2.16

Moiinvaziri, M. M. A. (2010). Motivational Orientation in English Language Learning. A study of Iranian Undergraduate Students. Retrieved from http:// www.using English.com/ teachers/ articles/ motivational- orientation- in - English-language-learning.htm.

Muftah, M., \& Shameem, R.G. (2013). Language Learning Motivation among Malaysian Pre-University Students. English Language Teaching, 6(3), 92-103 https://doi.org/10.5539/elt.v6n3p92

Mun, W. Y. (2011). A study of Instrumental and Integrative Motivations as Factors Influencing UTAR third- year Chinese Undergraduates in Learning ESL. Universiti Tunku AbdulRahman. Unpublished thesis, 254-258.

Punmanee, A. (1991). Creative Thinking. $3^{\text {rd }}$ edition. Bangkok: Yaimai.

Qashoa, S. H. (2006). Motivation among Learners of English in the Secondary School in the Eastern Coast of the UAE. Dubai. Institute of Education, British University 


\section{Macrothink}

International Journal of Learning and Development

ISSN 2164-4063 2018, Vol. 8, No. 4

Rahman, S. (2007). Orientation and Motivation in English Language Learning: a Study of Bangladeshi Students at Undergraduate Level. Asian EFL Journal, 7, 1-26.

Sass, E. J. (1989). Motivation in the College Classroom: what students tell us. Teaching of Psychology, 16(2), 86-88. https://doi.org/10.1207/s15328023top1602_15

Smadi, O. M. (1985). A Focused Efficient Method for Teaching Composition. FORUM, XXIV, 1(7), 35-36.

Tsai, C. C., \& I. Cheng Chang. (2010). English as a Foreign Language Learning Motivation among the Elderly Learners in Taiwan. 2010 International Conference on Gerontic Technology and Service Management. Nankai University of Technology, Nantou, Taiwan, 149-151.

Watcharapunyawong, S., \& Usaha, S. (2012). Thai EFL students' writing errors in different text types: The interference of the first language. English Language Teaching, 6(1), 67. https://doi.org/10.5539/elt.v6n1p67

Wimolmas, R. (2012). A Survey Study of Motivation in English Language Learning of First Year Undergraduate Students at Sirindhorn Institute of Technology.(SIIT), Thammasat University. http:// litu.tu.ac.th/journal/FLLTCP/ proceeding/904.PDF Pada Senin 23 Maret 2015 jam 09.30 .

Wink, P. (2013). An Investigation into Second Language Aptitude for Advanced Chinese Language Learning. The Modern Language Journal, 97(1), 109-130. https://doi.org/10.1111/j.1540-4781.2013.01428.x

Woolfolk. A. E. (1998). Educational Psychology. Boston: Allyn and Bacon.

\section{Copyright Disclaimer}

Copyright for this article is retained by the author(s), with first publication rights granted to the journal.

This is an open-access article distributed under the terms and conditions of the Creative Commons Attribution license (http://creativecommons.org/licenses/by/4.0/). 